\title{
Drilling of the Chelungpu Fault after the 1999 Chi-Chi, Taiwan Earthquake (Mw7.6): Understanding Physics of Faulting
}

by Kuo-Fong Ma and Hidemi Tanaka

The 21 September 1999 Chi-Chi, Taiwan earthquake (Mw 7.6) ruptured the $\mathrm{N}-\mathrm{S}$ trending Chelungpu fault with a major $90-\mathrm{km}$ structure that dips shallowly $\left(30^{\circ}\right)$ to the east, and principally slips within and parallel to bedding of the Pliocene Chinshui shale. A shallow borehole was drilled into the northern portion of the fault in the year 2000 (Fig. 1) in order to sample the slip zones that had large slip $(>10 \mathrm{~m})$ during the earthquake. The borehole was drilled at an angle of about $50^{\circ}$ to the west, penetrating the fault at a drilling depth of around $300 \mathrm{~m}$ in January, 2001 (Tanaka et al., 2002). The success of the shallow hole drilling led to the deeper holes drilling named TCDP (Taiwan Chelungpu-fault Drilling Project; Ma et al., 2006), which drilled two vertical holes 40 $\mathrm{m}$ apart (Hole A to a depth of $2 \mathrm{~km}$, and Hole B to a depth of $1.3 \mathrm{~km}$ ) and a side-track from Hole B (Hole C, depth 0.95$1.2 \mathrm{~km}$ ) about $2 \mathrm{~km}$ east of the surface rupture and $3 \mathrm{~km}$ to the south of the shallow hole, near the town of DaKeng (Fig. 1). TCDP carried out continuous coring for depths of $500 \mathrm{~m}$ to $2000 \mathrm{~m}, 950 \mathrm{~m}$ to $1300 \mathrm{~m}$, and $950 \mathrm{~m}$ to $1200 \mathrm{~m}$ for
Hole A, Hole B, and Hole C, respectively. Geophysical well logs were carried out in Hole A to collect seismic velocities, densities, and digital images.

For the shallow hole, the distributed fracture zone ranges from $285 \mathrm{~m}$ to $330 \mathrm{~m}$ depth, which contained nine slip zones. The neutron geophysical logs show that the porosity abruptly increases in the drilling interval between $285 \mathrm{~m}$ and $330 \mathrm{~m}$, suggesting that this zone would be the newest, being fractured during co-seismic slip by the Chi-Chi earthquake. Slip zones are basically composed of fault gouge and fault breccia. The fault gouge is brighter gray than host rocks. The boundary between fault gouge and host rock is gradual and is associated with a thin transition zone $(<2 \mathrm{~mm})$ from host rock to fault gouge. The mineral grains are more disaggregated nearer to the slip zone. Grains in fault gouge are of extremely fine cryptocrystalline materials $(<2 \mu \mathrm{m}$ diameter), and the maximum sizeis about $25 \mu$ min diameter. Microscopic textures were not indicative of frictional melting, such as

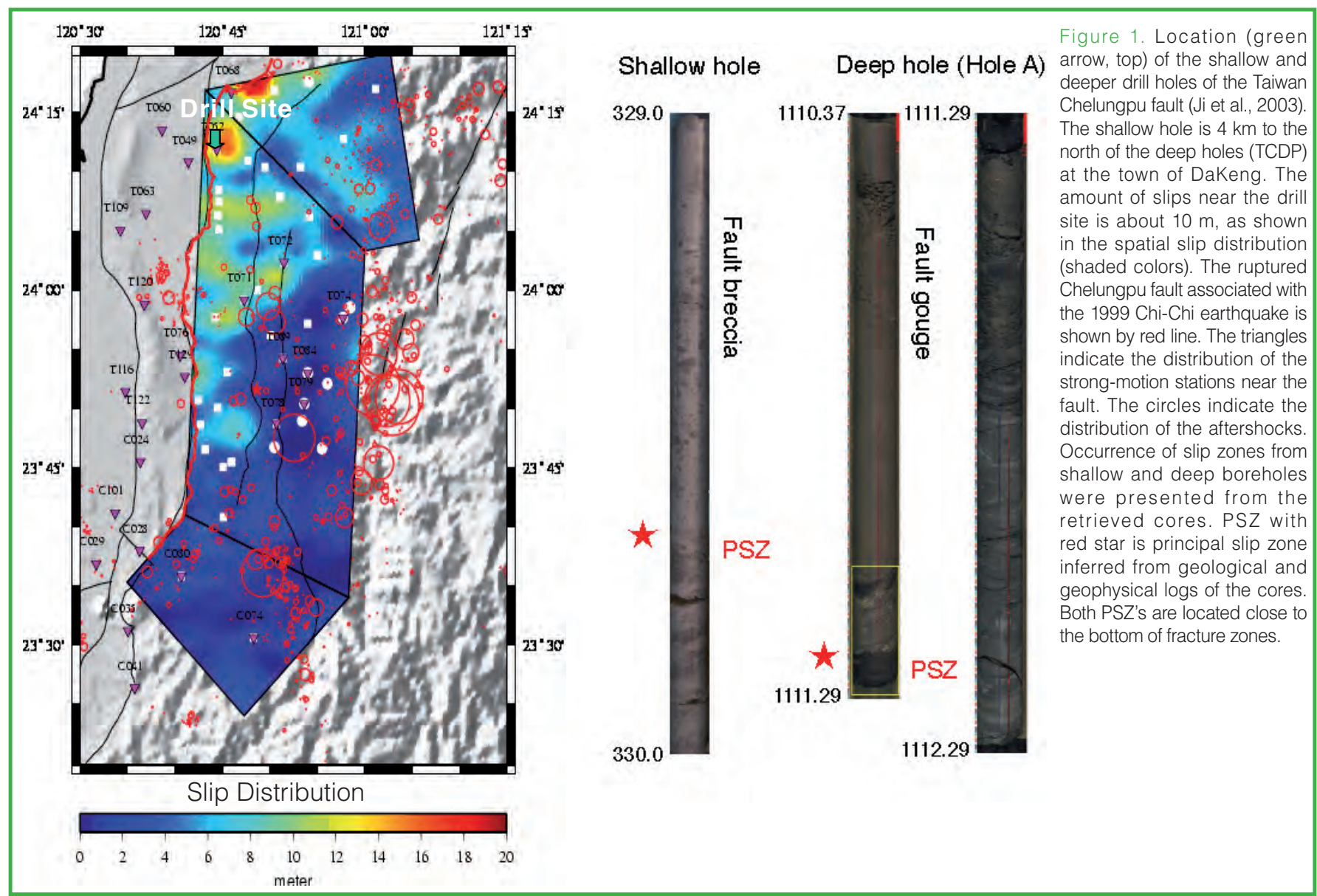


spherulitic or dendritic crystal morphology, microlites or grassy matrix in the slip zones. In the deep holes, the Chelungpu fault zone from the Hole A core is observed within the Chinsui shale at depths from $1105 \mathrm{~m}$ to $1115 \mathrm{~m}$, and consists of fractured rocks, fault breccia, and thin fault gouge layers. The degree of fracturing increases from the top to the bottom of the zone. Near the bottom of the broad zone of deformation, a 12-cm-thick primary slip zone (PSZ) can be identified based on the presence of ultra-fine grained fault gouge and increased fracture density at depths of $1111.23 \mathrm{~m}$ to $1111.35 \mathrm{~m}$. A corresponding feature was also found in Hole B core at the depths of $1136.50 \mathrm{~m}$ to $1136.62 \mathrm{~m}$, confirming the fault dip of $30^{\circ} \mathrm{E}$. The geophysical logging measurements of low seismic velocities and low electrical resistivity around $1111 \mathrm{~m}$ depth also confirm that this is the main fault zone (Wu et al., 2007). The PSZ observed in the core from Hole $\mathrm{C}$ after splitting and polishing shows several layers of slip zones associated with several repeating earthquakes. The individual slip zone has a thickness of about $2-3 \mathrm{~cm}$ with a 5 - $\mathrm{mm}$ ultra-fine grain zone at the bottom. Among the slip zones, the bottom zone in the PSZ, 2-cm in thickness, suffered the least disturbance from later events, suggesting that this narrow band might be the major slip zone (MSZ) that corresponds to the Chi-Chi earthquake. Other estimates of the thickness for the slip zone from nearby sites are 50-300 $\mu \mathrm{m}$ observed at the surface near the DaKeng drill site, and $1 \mathrm{~cm}$ from a fault core at a depth of $330 \mathrm{~m}$ in shallow drilling. These determinations of slip zone thicknesses are all from layers located near the bottom of the fracture zone. The variation of thickness of the slip zone at different depths might correspond to differences in normal stress as observed in Nojima fault core and other exhumed faults (Gratier et al., 2003; Tanaka et al., 2007).

The grain size distribution of the major slip zone was observed to estimate the surface fracture energy to compare with the seismic fracture energy to understand the energy partition of the earthquake. Direct measurements of the heat generated by this large earthquake were made for the shallow and deep holes. The local increases in the temperature profile across the fault observed both in shallow and deep holes were interpreted to be the residual heat generated during the earthquake. The frictional heat was calculated from temperature anomaly data observed at the depth associated with the identified slip zones of the Chi-Chi earthquake. Using the thermal parameters measured on-site with non-destructive methods as constraints, the analyses of the temperature anomalies lead to low estimates of the dynamic shear stress and to small values of the frictional coefficient. These results suggest the involvement of dynamic weakening mechanisms of faulting, such as thermal pressurization, during the large earthquake.

\section{References}

Gratier, J.-P., Favreau, P., and Renard, F., 2003. Modeling fluid transfer along California faults when integrating pressure solution crack sealing and compaction process. J. Geophys. Res., 108(No. B2):2104, doi:10.1029/2001JB000380.

Ji, C., Helmberger, D.V., Wald, D.J., and Ma, K.-F., 2003. Slip history and dynamic implications of the 1999 Chi-Chi, Taiwan, earthquake, J. Geophys. Res., 108(B9), 2412, doi:10.1029/ 2002JB001764.

Ma, K.-F., Tanaka, H., Song, S.-R., Wang, C.-Y., Hung, J.-H., Tsai, Y.-B., Mori, J., Song, Y.-F., Yeh, E.-C., Soh, W., Sone, H., Kuo, L.W., and Wu, H.-Y., 2006. Slip zone and energetics of a large earthquake from the Taiwan Chelungpu-fault drilling project. Nature, 444:473-476, doi:10.1038/nature05253.

Tanaka, H., Wang, C.-Y., Chen, W.-M., Sakaguchi, A., Ujiie, K., Ito, H., and, Ando, M., 2002. Initial science report of shallow drilling penetrating into the Chelungpu fault zone, Taiwan. Terr. Atm. Oceanic Sci., 13(3):227-251.

Tanaka, H., Omura, K., Matsuda, T., Ikeda, R., Kobayashi, K., Murakami, M., and Shimada, K., 2007. Architectural evolution of the Nojima fault and identification of the activated slip layer by Kobe earthquake.J. Geophys. Res., 112 (B7), B07304, doi:10.1029/2005JB003977.

Wu, H.-Y., Ma, K.-F., Zoback, M., Boness, N., Ito, H., Hung, J.-H., and Hickman, S., 2007. Stress orientations of Taiwan ChelungpuFault Project (TCDP) hole-A as observed from geophysical logs. Geophys. Res. Lett., 34:L01303, doi:10.1029/ 2006GL028050.

\section{Authors}

Kuo-Fong Ma, Department of Earth Science and Institute of Geophysics, National Central University, No.300, Johngda Rd., Johngli City, Taoyuan County 32001, Taiwan (R.O.C.), e-mail: fong@earth.ncu.edu.tw.

Hidemi Tanaka, Solid Earth Science Group, Department of Earth and Planetary Sciences, The University of Tokyo, Faculty of Science Building \#1, Hongou 7-3-1, Bunkyo-ku, Tokyo, 113-0033, Japan. 